\title{
Вплив улінастатину на метаболізм циркулюючих лейкоцитів та сироватковий рівень негістонових білків 1 високомобільної групи у хворих з гострим панкреатитом
}

\author{
Я. М. Сусак ${ }^{1}$, О. І. Зуб ${ }^{2}$, О. М. Лобанова ${ }^{2}$ Н. В. Сенчило ${ }^{3}$ О. Г. Федорчук ${ }^{4}$, Л. М. Сківка ${ }^{3}$ \\ ${ }^{1}$ Національний медичний університет імені О. О. Богомольця, м. Київ, \\ ${ }^{2}$ Київська міська клінічна лікарня швидкої медичної допомоги, \\ ${ }^{3}$ Навчально-науковий центр "Інститут біології та медицини” Київського національного університету імені Тараса Шевченка, \\ ${ }_{4}^{4}$ Інститут експериментальної патології, онкології та радіобіології імені Р. Є. Кавецького НАН України, м. Київ
}

\section{Impact of ulinastatin on metabolism of circulating leukocytes and the serum level of nonhistonic high mobility group box 1 proteins in the patients, suffering an acute pancreatitis}

\author{
Ya. M. Susak ${ }^{1}$, O. I. Zub², O. M. Lobanova ${ }^{2}$, N. V. Senchylo ${ }^{3}$, O. G. Fedorchuk $^{4}$, L. M. Skivka ${ }^{3}$ \\ ${ }^{1}$ Bogomolets National Medical University named, Kyiv, \\ ${ }^{2}$ Kyiv's Municipal Clinical Hospital of Urgent Medical Aid, \\ ${ }^{3}$ Institute of Biology and Medicine of the Taras Shevchenko National University, Kyiv, \\ ${ }^{4}$ Kavetskyi Institute of Experimental Pathology, Oncology and Radiobiology, Kyiv
}

\begin{abstract}
Реферат
Мета. Дослідити вплив лікування хворих з гострим панкреатитом (ГП) з використанням препарату улінастатин (УС) на функціональний стан циркулюючих лейкоцитів та сироватковий рівень негістонових білків 1 високомобільної групи (High Mobility Group Box 1 protein - HMGB1).

Матеріали і методи. У дослідження включено 60 хворих з ГП, яких лікували у хірургічному відділенні № 2 Київської міської клінічної лікарні швидкої медичної допомоги. Про стан метаболізму циркулюючих фагоцитів судили за показниками продукції реактивних форм кисню (РФК) та фагоцитарною активністю, які визначали методом проточної цитометрії. Для визначення сироваткового рівня HMGB1 застосовували метод імуноферментного аналізу.

Результати. Про позитивний терапевтичний ефект УС свідчили зниження синтезу РФК циркулюючими лейкоцитами (в середньому у 2 рази), помірне посилення фагоцитарної активності циркулюючих моно- та поліморфноядерних фагоцитів, зниження сироваткового рівня HMGB1 на 27\%.

Висновки. Включення до складу лікувального алгоритму УС посилює протизапальний та антиоксидантний ефекти лікування хворих з ГП.

Ключові слова: гострий панкреатит; улінастатин; метаболізм лейкоцитів; негістонові білки 1 високомобільної групи.

Abstract

Objective. To investigate the impact on treatment of patients, suffering an acute pancreatitis (AP), using preparation ulinastatin (US) on functional state of circulating leukocytes and the serum level of nonhistonic high mobility group box 1 protein (HMGB1). Materials and methods. Into the investigation 60 patients with an AP were included, who were treated in Department of Surgery № 2 of the Kyiv's Municipal Clinical Hospital of Urgent Medical Aid. The indices of production of the oxygen reactive forms (ORF), which were determined by flowcytometry method, witnessed the state of the circulating phagocytes metabolism. Method of the immunoenzyme analysis was applied for determination of the HMGB1 level in serum.

Results. Propositive therapeutic effect of US have witnessed the lowering of the ORF synthesis by circulating leukocytes (twice at average), moderate strengthening of phagocytic activity of circulating mono- and polymorphonuclear phagocytes, lowering of the serum level of HMGB1 by $27 \%$.

Conclusion. Inclusion of US into content of the treatment algorithm strengthens its anti-inflammatory and antioxidant effects in the patients, suffering an acute pancreatitis.

Keywords: acute pancreatitis; ulinastatin; metabolism of leukocytes; nonhistonic High Mobility Group Box 1 proteins (HMGB1)
\end{abstract}

Пошук і впровадження в практику лікування ГП препаратів із ферментінгібіторною і протизапальною дією залишаються актуальними. Одним із таких препаратів є УС інгібітор серинових протеаз, у тому числі еластази нейтрофілів, з протизапальною активністю, який успішно застосовують для лікування ГП [1, 2]. УС властива здатність гальмувати синтез і секрецію прозапальних цитокінів шляхом блокування NFkappaB-залежного сигналінгу [3], а також стимулювати диференціювання регуляторних Т-клітин
[4]. Одним із важливих механізмів протизапальної дії УС, виявлених в експериментальних дослідженнях, $є$ інгібування виділення у позаклітинний простір потужних ендогенних алармінів - HMGB1 [5]. Джерелом підвищення сироваткового рівня НMGB1 у хворих з ГП є некротизовані клітини підшлункової залози, з яких внаслідок непрограмованої загибелі пасивно виділяються ці білки, а також активовані клітини імунної системи, зокрема циркулюючі фагоцити. Циркулюючий HMGB1 належить до так званих 
пізніх прозапальних цитокінів і відіграє виключну роль у формуванні множинної органної дисфункції у хворих 3 ГП [6]. НMGB1 залучається до формування множинної органної дисфункції через свою здатність зв'язуватися з низкою рецепторів з NFkappaB-залежним сигналінгом, експресованих на мієлоїдних та лімфоїдних клітинах (моноцитах, нейтрофілах, дендритних клітинах, лімфоцитах): толл-подібними рецепторами (Toll-Like Receptor - TLR), а саме TLR2, TLR4 та TLR9, рецептором для кінцевих продуктів глікозилювання (Receptor for Advanced Glycation End Produc - RAGE) та тригерним рецептором, експресованим на мієлоїдних клітинах-1 (Triggering Receptor Expressed on Myeloid Cells-1 - TREM-1). Встановлено, що лігація цих рецепторів викликає прозапальну активацію мієлоїдних клітин, що супроводжується посиленням синтезу ними РФК і азоту та низки прозапальних медіаторів, котрі ініціюють розвиток системного запального процесу з множинним ушкодженням екстрапанкреатичних органів [7,8].

Мета дослідження: вивчити вплив лікування хворих 3 ГП з використанням УС на функціональний стан циркулюючих лейкоцитів та сироватковий рівень HMGB1.

\section{Матеріали і методи дослідження}

Всього у дослідженні взяли участь 60 пацієнтів 3 діагностованим ГП, яких лікували у хірургічному відділенні №2 Київської міської клінічної лікарні швидкої медичної допомоги. Жінок було 22, чоловіків - 38. Середній вік пацієнтів становив (47 \pm 4$)$ роки. Діагноз та тяжкість стану хворих з ГП встановлювали за переглянутою класифікацією Атланта - 2012 [9]. Усі хворі отримували терапію згідно зі Стандартами надання медичної допомоги хворим із невідкладними хірургічними захворюваннями органів черевної порожнини, затвердженими Наказом Міністерства охорони здоров’я України № 297 від 02.04.2010 р.

Для реалізації поставленої мети дослідження хворих розподілили на три групи: 1-ша група - 10 хворих з легким перебігом ГП (ЛГП без органної недостатності, місцевих та/або системних ускладнень); 2-га група (контрольна) - 25 хворих з середньої тяжкості та тяжким перебігом ГП, яких лікували без використання УС (СТТГП); 3-тя група (основна) - 25 хворих з середньої тяжкості та тяжким перебігом ГП, які додатково до стандартної тера- пії отримували УС (Bharat Serums and Vaccines Ltd., Індія) двічі на добу о 10 та 22 год у дозі 200 тисяч МО протягом 5 діб починаючи не пізніше ніж через 48 год з моменту госпіталізації (СТТГПУС).

Зразки крові для аналізу метаболізму циркулюючих лейкоцитів, а також сироваткового рівня HMGB1 брали під час госпіталізації у всіх пацієнтів, а також після закінчення курсу лікування у хворих контрольної та основної груп. У дослідженнях використовували венозну кров, взяту натще з антикоагулянтом. Про метаболічну активність циркулюючих лейкоцитів (моноцитів, нейтрофілів та лімфоцитів) судили за фагоцитарною активністю, використовуючи як об'єкт фагоцитозу S. aureus Cowan [10], а також за внутрішньоклітинною продукцією ними РФК, яку оцінювали методом проточної цитофлуориметрії з незначними модифікаціями, описаними нами раніше [11]. Для диференційованого аналізу моноцитів, нейтрофілів та лімфоцитів використовували гейтування. Функціональний стан клітин оцінювали за наявністю або відсутністю метаболічного резерву функції після обробки досліджуваного зразка крові форбол-міристат-ацетатом (ФМА) in vitro. Для статистичного аналізу результатів використовували методи варіаційної статистики з розрахунком $\mathrm{M} \pm \mathrm{SD}$. Відмінності між порівнюваними групами аналізували з використанням критерію Вілкоксона-Манна-Уітні і вважали статистично значущими, коли значення р дорівнювали або були менші 0,05.

\section{Результати}

Застосування стандартного лікувального алгоритму, а також включення до його складу препарату УС супроводжувалося позитивними змінами в метаболізмі циркулюючих лейкоцитів: лімфоцитів і фагоцитів (нейтрофілів і моноцитів) у хворих з ГП.

Згідно з результатами наших досліджень для показників киснезалежної метаболічної активності циркулюючих лейкоцитів у хворих з ГП була характерна значна індивідуальна варіабельність, особливо у разі лікування середньої тяжкості та тяжкої форм хвороби з використанням УС, що зумовило необхідність додаткового розподілу основної групи на дві підгрупи залежно від реакції циркулюючих лейкоцитів на препарат: СТТГПУС I (n=17) i СТ ТГПУС II (n=8). Для циркулюючих лейкоцитів усіх по-
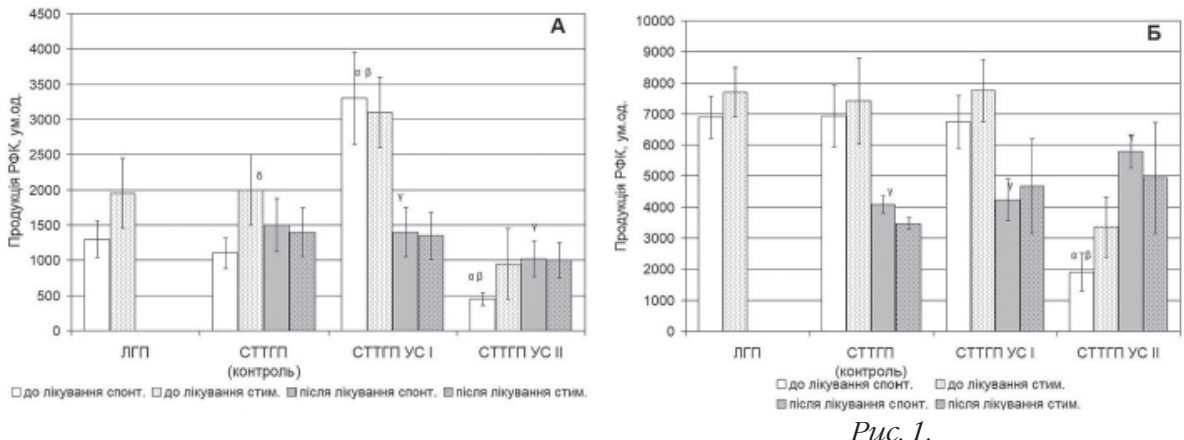

Puc. 1.

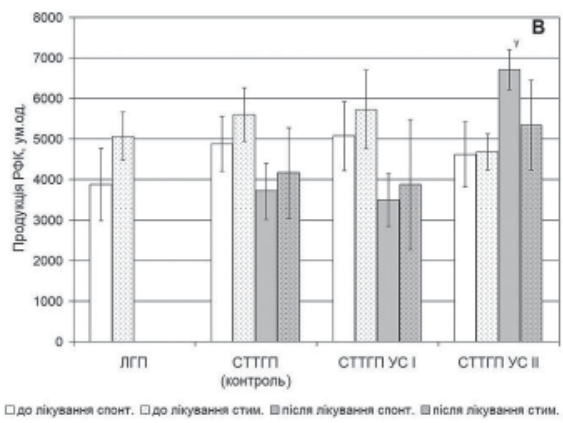

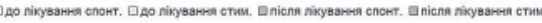

Вплив лікування з використанням УС на оксидативний метаболізм циркулюючих лімфоцитів (А), моноцитів (Б),

гранулочитів (В) у хворих з ПП: $\alpha-p \leq 0,05$ у порівнянні з пацієнтами з ЛГП; $\beta-p \leq 0,05$ у порівнянні з пацієнтами з середнъої тяжкості та тяжкою формами ГП, що отримували стандартне лікування; $\gamma$ - $\leq \leq 0,05$ у порівнянні з аналогічним показником до лікування; $\delta$ - p $\leq 0,05$ у порівнянні з аналогічнии показником нестимульованої проби. 
Puc.2.

Вплив лікування з використанням УС на фагоцитоз циркулюючих гранулочитів (A) та моноцитів (Б) у хворих з ГП; $\alpha-p \leq 0,05$ у порівнянні з пачієнтами з ЛГП; $\gamma-p \leq 0,05$ у порівнянні з аналогічним показником долікування.
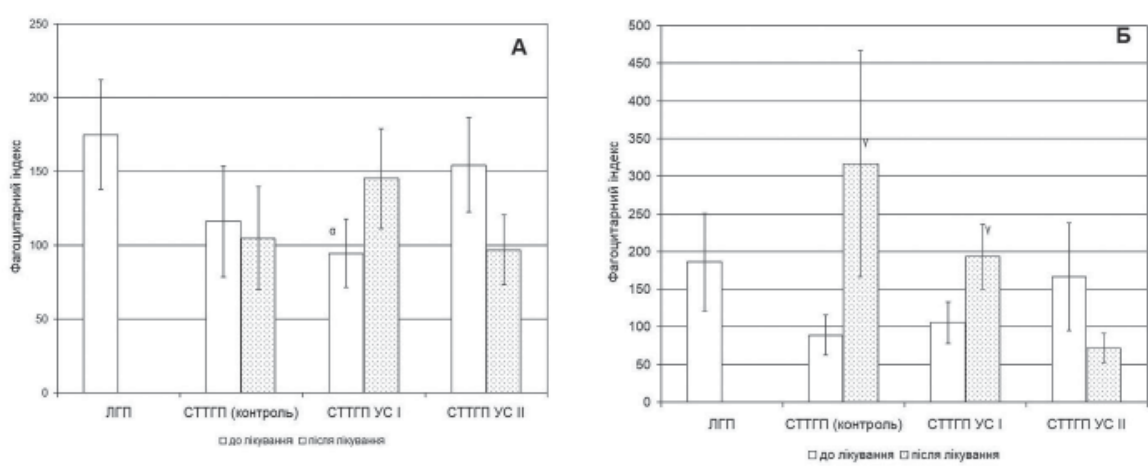

пуляцій як у хворих з легким ГП, так і у хворих з середньої тяжкості та тяжким ГП була характерна відсутність функціонального резерву оксидативного метаболізму.

Під впливом лікування із застосуванням УС у пацієнтів першої підгрупи основної групи знизився оксидативний метаболізм циркулюючих лімфоцитів у 2,5 разу (рис. $1 A$ ), моноцитів - в 1,6 разу (рuс. 15 ) і помірно знизився оксидативний метаболізм гранулоцитів периферичної крові (рис. 1B). У пацієнтів другої підгрупи основної групи оксидативний метаболізм усіх досліджуваних популяцій лейкоцитів периферичної крові збільшився після проведеного лікування. Слід зазначити, що до лікування значення цього показника у пацієнтів другої підгрупи основної групи були вірогідно нижчими у порівнянні з пацієнтами першої та контрольної групи.

Фагоцитарна активність циркулюючих нейтрофілів і моноцитів у переважної більшості хворих із середньої тяжкості та тяжкою формами ГП була знижена порівняно з аналогічним показником у хворих з легким перебігом захворювання (рис. 2).

У контрольній групі пацієнтів після завершення стандартного терапевтичного курсу не зафіксовано змін у поглинальній здатності циркулюючих поліморфноядерних фагоцитів (рис. 2A), спостерігали статистично вірогідне посилення поглинальної здатності мононуклеарних фагоцитів (рис. 2Б). Лікування із застосуванням УС у пацієнтів першої підгрупи основної групи приводило до посилення поглинальної активності фагоцитів обох популяцій. У другій підгрупі спостерігали помірне статистично невірогідне зниження фагоцитарної активності циркулюючих клітин після проведеного лікування. Слід відмітити, що до лікування значення фагоцитарного індексу у хворих другої підгрупи основної групи були дещо вищими у порівнянні з аналогічним показником у хворих першої підгрупи.

Сироватковий рівень ендогенного аларміну HMGB1 у всіх обстежених пацієнтів перевищував показники здорових донорів, референтні межі яких мають діапазон 0,161 5,47 нг/мл. Показники сироваткової концентрації HMGB1 у пацієнтів з ГП, як і показники метаболічної активності лейкоцитів, також характеризувалися індивідуальною варіабельністю, більшою мірою у пацієнтів з тяжким перебігом захворювання.

Після лікування у хворих з ГП сироватковий рівень HMGB1 знижувався, однак статистично вірогідним це зниження було лише у разі терапії із застосуванням УС (рис.3).

\section{Обговорення}

Функціональний стан лейкоцитів, у тому числі фагоцитів, і сироватковий рівень ендогенних алармінів HMGB1 $є$ загальновизнаними показниками для характеристики запального процесу і оцінки ефективності застосування протизапальних засобів у лікуванні патологічних станів запальної етіології. Фагоцити - ключові ефекторні клітини запального процесу - відіграють виключну роль у патогенезі ГП [12]. Проведені нами попередні дослідження виявили прогностичну значущість оцінки функціонального стану циркулюючих фагоцитів у хворих з ГП і можливість використання характеристики метаболічної активності цих клітин для оцінки ефективності застосування імуномодуляторних засобів у лікуванні ГП [13 - 15]. Для оцінки функціонального стану фагоцитів ми використали показник оксидативного метаболізму та поглинальної (фагоцитарної) активності цих клітин. Оксидативний метаболізм мононуклеарних (моноцитів) і поліморфнонуклеарних (нейтрофілів) фагоцитів залучений до їх участі у реакціях запалення як деструктивної (інфекційні та асептичні запальні процеси), так і репаративної (загоєння ран) спрямованості. Синтез РФК лімфоцитами виявлений порівняно недавно [16]. Механізми його активації практично не досліджені. Припускають, що генерація активних сполук кисню у лімфоцитах відбувається із залученням синтази оксиду азоту (NO-синтази), NADH оксидази та деяких інших ферментів. Доведено, що посилення киснезалежного метаболізму лімфоцитів пов'язане з їх функціональною активацією у процесі адаптивної імунної реакції запальної (Th1) спрямованості. Як зазначено вище, УС має здатність гальмувати функціональ-

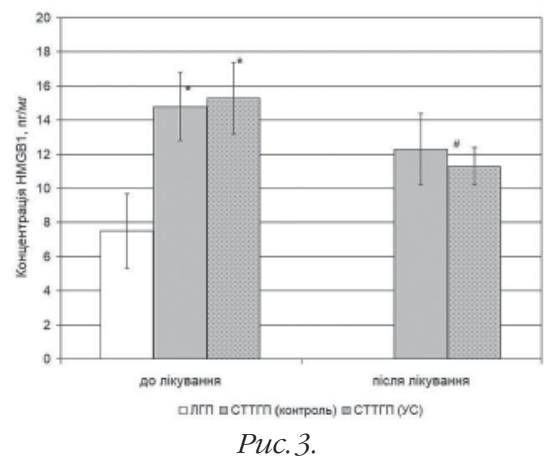

Вплив лікування з використанням УС на сироватковий рівень HMGB1 у хворих з ГП: " - $\leq$ 0,05 у порівнянні з пацієнтами 3 ЛГП; \# - $\leq \leq, 05$ у порівнянні з аналогічним показником долікування. 
не дозрівання Th1-лімфоцитів [4] і стимулювати дозрівання регуляторних Т-клітин, що є одним із механізмів його протизапальної дії.

Поглинальна активність фагоцитів відіграє важливу роль у патогенезі і прогресуванні ГП. Порушення фагоцитарної функції резидентних макрофагів спричиняє патологічні зміни у кліренсі загиблих ацинарних клітин, наслідком чого є розвиток локального запального процесу. Послаблення фагоцитарної функції циркулюючих фагоцитів призводить до послаблення їх патрульної функції в імунному захисті і створює підгрунтя для розвитку інфекційних ускладнень ГП $[17,18]$.

Характерною особливістю функціонального стану циркулюючих лейкоцитів є відсутність функціонального резерву оксидативного метаболізму, що вказує на максимальну активацію цієї функції клітин, типову для їх запальної метаболічної поляризації [12]. Групу хворих, котрі отримували УС, було розподілено на дві підгрупи залежно від реакції циркулюючих лейкоцитів на препарат. У першій підгрупі доповнення стандартної схеми лікування препаратом УС супроводжувалося статистично вірогідним зниженням продукції РФК циркулюючими лейкоцитами всіх досліджуваних популяцій, значно більш вираженим у порівнянні з показниками групи пацієнтів, яких лікували без застосування УС, що вказує на більш виражений протизапальний вплив лікування із застосуванням даного препарату в порівнянні із стандартною схемою. Одним із механізмів антиоксидантної дії УС, зареєстрованої за результатами наших досліджень, може бути його здатність активувати синтез гемоксигенази 1 - потужного фермента антиоксидантного захисту [19]. У хворих другої підгрупи було зареєстровано незначне посилення оксидативного метаболізму лейкоцитів після проведеного лікування із застосуванням УС. У пацієнтів цієї підгрупи зазначені функціональні показники до лікування мали дуже низькі значення, що може свідчити про спонтанну резолюцію запалення. Одночасно з посиленням генерації РФК функціональний стан циркулюючих моноцитів і нейтрофілів у хворих із середньої тяжкості і тяжким перебігом ГП характеризувався зниженням їх фагоцитарної активності. Це узгоджується з опублікованими даними, згідно з якими зниження поглинальної здатності циркулюючих фагоцитів - типова ознака їх функціонального стану в умовах розвитку ГП $[12,18]$. Крім того, генетично детерміновані вади поглинальної здатності мононуклеарних фагоцитів вважають одним із патогенетичних чинників панкреатиту [12, 17].

Проведення стандартного лікування сприяло відновленню фагоцитарної функції лише мононуклеарних фагоцитів. У пацієнтів зі зниженим після використання УС оксидативним метаболізмом зареєстровано посилення поглинальної активності фагоцитів обох популяцій. У хворих другої підгрупи поглинальна активність фагоцитів після застосування УС помірно знижувалася. Значення фагоцитарного індексу до лікування у пацієнтів цієї підгрупи дорівнювали аналогічним показникам у пацієнтів з легкою формою перебігу хвороби. Зазначені результати дають підстави припустити, що спрямованість імуномодуляторного впливу терапії з використанням УС зале- жить від вихідних значень показників функціональної активності лейкоцитів, що створює підгрунтя для розробки персоналізованих схем застосування препарату у хворих з ГП. Однак таке припущення обумовлює потребу проведення додаткових досліджень зі збільшенням кількості пацієнтів у групі обстеження з метою виявлення закономірності впливу препарату на зазначені показники імунної реактивності у хворих з ГП.

Одночасно з нормалізацією функціонального стану циркулюючих лейкоцитів після проведення лікування 3 використанням УС ми зафіксували зниження сироваткової концентрації ендогенних алармінів HMGB1, що може бути одним із механізмів зниження прозапальної активації лейкоцитів у хворих з ГП.

\section{Висновки}

1. Терапевтична ефективність використання УС супроводжувалася статистично вірогідним зниженням продукції РФК циркулюючими лейкоцитами у хворих з ГП, більш вираженим у порівнянні із впливом стандартної схеми лікування, що вказує на протизапальну та антиоксидантну дію препарату.

2. Включення УС до складу комплексного лікування хворих з ГП приводило до посилення фагоцитарної активності моно- та поліморфнонуклеарних фагоцитів периферичної крові, що є ознакою резолюції запалення і патогенетичної спрямованості терапії, та до статистично вірогідного зниження сироваткової концентрації аларміну HMGB1 - одного з основних цитокінів, залучених до формування множинної органної дисфункції у цих хворих.

3. 3 огляду на значну індивідуальну варіабельність досліджуваних показників необхідно збільшити кількість пацієнтів у перспективі напрацювання персоналізованих підходів до застосування УС у лікуванні ГП.

\section{References}

1. Wang G, Liu Y, Zhou SF, Qiu P, Xu L, Wen P, et al. Effect of Somatostatin, Ulinastatin and Gabexate on the Treatment of Severe Acute Pancreatitis. Am J Med Sci. 2016;351(5):506-12. doi: 10.1016/j.amjms.2016.03.013.

2. Atal SS, Atal S. Ulinastatin - a newer potential therapeutic option for multiple organ dysfunction syndrome. J Basic Clin Physiol Pharmacol. 2016; 27(2):91-9. doi: 10.1515/jbcpp-2015-0003.

3. Li_D, Ji H, Zhao B, Xu C, Xia W, Han L, et al. Therapeutic effect of ulinastatin on pulmonary fibrosis via downregulation of TGF $\beta 1$, TNF $\alpha$ and NFkB. Mol Med Rep. 2018;17(1):1717-23. doi: 10.3892/ mmr.2017.8056.

4. Pan Y, Fang H, Lu F. Ulinastatin ameliorates tissue damage of severe acute pancreatitis through modulating regulatory T cells. J Inflamm. (Lond) 2017;14:7. doi: 10.1186/s12950-017-0154-7.

5. Luo Y, Che W, Zhao M. Ulinastatin post-treatment attenuates lipopolysaccharide-induced acute lung injury in rats and human alveolar epithelial cells. Int J Mol Med. 2017;39(2): 297-306. doi: 10.3892/ ijmm.2016.2828.

6. Yang R, Tenhunen J, Tonnessen TI. HMGB1 and Histones Play a Significant Role in Inducing Systemic Inflammation and Multiple Organ Dysfunctions in Severe Acute Pancreatitis. Int. J. Inflam. 2017:1817564. doi: $10.1155 / 2017 / 1817564$

7. Vourc'h M, Roquilly A, Asehnoune K. Trauma-Induced Damage-Associated Molecular Patterns-Mediated Remote Organ Injury and Immunosuppression in the Acutely Ill Patient. Front Immunol. 2018;9:1330. doi: 10.3389/fimmu.2018.01330.

8. Chan JK, Roth J, Oppenheim JJ, Tracey KJ, Vogl T, Feldmann M, et al. Alarmins: awaiting a clinical response. J Clin Invest. 2012;122(8):271119. doi: $10.1172 / J C I 62423$. 
9. Banks PA, Bollen TL, Dervenis C, Gooszen HG, Johnson CD, Sarr MG, et al. Acute Pancreatitis Classification Working Group. Classification of acute pancreatitis-2012: revision of the Atlanta classification and definitions by international consensus. Gut. 2013;62(1):102-11. doi: 10.1136/ gutjnl-2012-302779.

10. Reiner NE, editor. Macrophages and dendritic cells. Methods and Protocols. NY, Humana Press; 2009: 368 s. P. DOI 10.1007/978-1-59745396-7.

11. Rudyk MP, Pozur VV, Voieikova DO, Hurmach YV, Khranovska NM, Skachkova OV, et al. Sex-based differences in phagocyte metabolic profile in rats with monosodium glutamate-induced obesity. Sci Rep. 2018;8(1):5419. doi: 10.1038/s41598-018-23664-0.

12. Shrivastava P, Bhatia M. Essential role of monocytes and macrophages in the progression of acute pancreatitis. World J Gastroenterol. 2010;16(32):3995-4002. doi:10.3748/wjg.v16.i32.3995.

13. Susak YaM, Dyrda OO, Skivka LM, Fedorchuk OH, vynakhidnyky; Dyrda OO, patentovlasnyk. Sposib prohnozuvannia hniino-septychnykh uskladnen hostroho nekrotychnoho pankreatytu. Patent Ukrainy No 76812. 2013 sich 10

14. Susak I, Skivka L, Tkachenko O, Khomenko I, Dyrda O. Assessment of circulating phagocyte functional state for the prediction of suppurative complications in patients with acute necrotizing pancreatitis. Pancreatology. 2015 June;15(3 Supp 1): S6. doi: 10.1016/j.pan.2015.05.059.
15. Susak YaM, Dyrda OO, Skivka LM, Fedorchuk OH, vynakhidnyky; Dyrda OO, patentovlasnyk. Sposib prohnozuvannia efektyvnosti imunomoduliatora pry kompleksnomu likuvanni khvorykh na hostryi nekrotychnyi pankreatyt. Patent Ukrainy No 76813. 2013 sich 10.

16. Mirzaei S, Hadadi Z, Attar F, Mousavi SE, Zargar SS, Tajik A, et al ROS-mediated heme degradation and cytotoxicity induced by iron nanoparticles: hemoglobin and lymphocyte cells as targets. J Biomol Struct Dyn. 2017;18:1-11. doi: 10.1080/07391102.2017.1411832.

17. Oiva J, Mustonen H, Kylänpää ML, Kuuliala K, Siitonen S, Kemppainen E, et al. Patients with acute pancreatitis complicated by organ dysfunction show abnormal peripheral blood polymorphonuclear leukocyte signaling. Pancreatology. 2013;13(2):118-24. doi: 10.1016/j. pan.2013.01.010.

18. Song D, Song G, Niu Y, Song W, Wang J, Yu L, et al. Ulinastatin activates haem oxygenase 1 antioxidant pathway and attenuates allergic inflammation. Br J Pharmacol. 2014;171(19):4399-412. doi: 10.1111/ bph. 12780 .

19. Bartel M, Hänsch GM, Giese T, Penzel R, Ceyhan G, Ketterer K, et al. Abnormal crosstalk between pancreatic acini and macrophages during the clearance of apoptotic cells in chronic pancreatitis. J Pathol. 2008;215(2):195-203. doi: 10.1002/path.2348. 